\title{
Ambulatory intravenous antibiotic therapy in Quebec: The Hôpital Charles LeMoyne experience in 1996
}

Laurent Delorme MD FRCPC, Charles Frenette MD FRCPC, Isabelle Le Corre MD FRCPC, Julie Duchesne BPharm MSc, Carole Delorme BPharm MSc, Pauline Plourde Inf BSc MEd

L Delorme, C Frenette, I Le Corre, J Duchesne, C Delorme, P Plourde. Ambulatory intravenous antibiotic therapy in Quebec: The Hôpital Charles LeMoyne experience in 1996. Can J Infect Dis 2000;11(Suppl A):6A-10A.

From January 1, 1996 to December 31, 1996, 343 patients received outpatient intravenous antibiotic therapy at Charles LeMoyne Hospital, a 436-bed, acute care hospital in Greenfield Park, south of Montréal, Québec. The infectious diseases department saved 2660 bed-days using outpatient therapy. The mean duration of outpatient therapy was 7.76 days; $81.6 \%$ of patients were admitted to the program directly from the emergency room, or outpatient hospital clinics or private offices in the community. Hospitalized patients constituted only $18.4 \%$ of admissions to the outpatient intravenous antibiotic therapy program. Forty per cent of the surgical/medical staff participated in the program and they were able to generate a significant impact by diverting patients to outpatient therapy. Two types of patients can benefit from an outpatient intravenous antibiotic therapy program. One group of patients needs empirical short term therapy and can be switched to oral sequential therapy after two to five days of outpatient intravenous antibiotic therapy. A second group of patients needs specific long term therapy for the full duration of the antibiotic therapy. Empirical short term therapy can be managed by emergency department or hospital-based primary physicians, or medical/surgical specialists. Specific long term therapy can be managed by microbiology/infectious disease specialists or medical/surgical specialists. Hospitals that want to relieve pressure on emergency rooms and hospital bed demands should create facilities for both types of patients. Cefazolin and gentamicine/tobramycine were the most commonly used antibiotics in empirical short term therapy and in terms of number of patients treated. Ceftriaxone and vancomycin were most commonly used for long term therapy. The Drug acquisition antibiotic cost was $\$ 73,117$ but constituted only $20 \%$ of the total outpatient intravenous antibiotic therapy cost. The per diem ambulatory cost was $\$ 140 /$ patient/day.

Key Words: Outpatient therapy; Intravenous antibiotic therapy; Outpatient per diem cost

\section{Antibiothérapie intraveineuse ambulatoire au Québec : L'expérience de l'hôpital Charles LeMoyne en 1996}

RÉSUMÉ : Entre le 1er janvier 1996 et le 31 décembre 1996, 343 patients ont reçu une antibiothérapie intraveineuse ambulatoire à l'hôpital Charles LeMoyne, un hôpital de soins aigus de 436 lits, situé à Greenfield Park sur la rive sud de Montréal, au Québec. Le service d'infectiologie a épargné 2660 jours/lits grâce au traitement externe. La durée moyenne du traitement a été de 7,76 jours, 81,6\% des patients ont été admis au programme, directement à partir des urgences ou des cliniques ambulatoires de l'hôpital ou des cabinets privés avoisinants. Les patients hospitalisés ne composaient que $18,4 \%$ des admissions au programme d'antibiothérapie intraveineuse ambulatoire. Quarante pour cent du personnel chirurgical et médical a participé au programme et a pu exercer un impact significatif en orientant les patients vers le

voir page suivante

Department of Infectious Diseases, Hôpital Charles Le Moyne, Greenfield Park, Quebec

Correspondance and reprints: Dr Laurent Delorme, Département de Microbiologie Infectiologie, Hôpital Charles LeMoyne,

3120 boul Taschereau, Greenfield Park, Québec G4V 2H1. Telephone 450-466-5000 ext 2835, fax 450-466-5778,

e-mail laurent.delorme@videotron.ca 
traitement ambulatoire. Deux types de patients peuvent bénéficier du programme d'antibiothérapie intraveineuse ambulatoire. L'un requiert une antibiothérapie intraveineuse empirique et peut passer au traitement oral après deux à cinq jours d'antibiothérapie intraveineuse ambulatoire. Le deuxième requiert un traitement à long terme spécifique pour la durée entière de l'antibiothérapie. Le traitement empirique court peut être géré par le service des urgences ou par les médecins de premier recours attachés à l'hôpital ou encore par des médecins ou chirurgiens spécialistes. Le traitement spécifique à long terme peut être pris en charge par les spécialistes en microbiologie et en infectiologie ou par les médecins et chirurgiens spécialistes. Les hôpitaux qui veulent alléger le fardeau de leurs urgences et réduire les demandes de lits hospitaliers devraient mettre sur pied des programmes pour les deux types de patients. La céfazoline et la gentamicine/tobramycine ont été les antibiotiques le plus couramment utilisés en traitement empirique bref et pour ce qui est sdu nombre de patients traités. La ceftriaxone et la vancomycine ont été les plus utilisées pour le traitement à long terme. Le coût des antibiotiques a été de 73177 \$, mais n'a représenté que $20 \%$ des coûts totaux de l'antibiothérapie intraveineuse ambulatoire. Le coût du traitement ambulatoire a été de 140 \$/patient/jour.

$\mathrm{O}$ utpatient intravenous antibiotic therapy was introduced to the province of Quebec through pilot studies initiated in Quebec City from 1984 to 1987 (1-3). The pilot studies were set in university hospitals, using multidisciplinary teams comprising an infectious disease specialist, a pharmacist, a nurse trained in venous access and a hospital administrator. The infections most commonly treated were osteomyelitis and septic arthritis, and great cost savings were achieved. However, new alternatives to hospitalization were slow to be developed because of fixed budget rules and no incentive to support outpatient services.

In 1995, a major health care reform called 'défi qualitéperformance' (4) was initiated by each regional health board. This initiative planned to decrease public hospitals' budgets and the number of beds to liberate new funds and achieve a major medical/surgical 'virage ambulatoire'. This reform allowed the promotion of less costly alternatives to hospitalization, such as outpatient intravenous antibiotic therapy. In the Monteregie region, a large area of 1,307,423 people, situated on the south shore of Montreal, this health reform was applied to 10 community hospitals located in the region. Almost every community hospital initiated a local outpatient intravenous antibiotic program as part of their hospital reform. We present the experience of the largest hospital in Monteregie, the Hôpital Charles LeMoyne.

\section{PROGRAM DESCRIPTION}

The Hôpital Charles LeMoyne is a 436-bed, acute care hospital with a major emergency centre and a regional trauma centre. It provides basic care to a population of 450,000 people and receives 60,856 visits per year to the emergency department; $80 \%$ of the 14,856 admissions went through the emergency department in the 1994/95 fiscal year. Pressure to access care is very strong for patients who are cared for by 64 general physicians and 136 active surgical/medical specialists. In 1994/95, the hospital per diem cost was $\$ 412 /$ day, and the annual closed budget envelope for Hôpital Charles Le Moyne was $\$ 93$ million.

To generate a rapid and significant impact on cost, infectious disease specialists and organizers of the outpatient antibiotic intravenous therapy program requested the participation of a large proportion of the medical/surgical staff. Infectious disease specialists thought that outpatient antibiotic intravenous therapy had been well studied and successful results had been published (5-9). They also thought that the Canadian guidelines (10) could be used to teach active medical/surgical staff at Hôpital Charles LeMoyne. The infectious disease specialists asked for the same professional support from hospital nursing and pharmacy for outpatients as received by inpatients. The infectious disease specialists also believed that with proper professional support and simple, locally established guidelines, medical/surgical staff would participate together as a group in the 'virage ambulatoire' as primary providers of an alternative to hospitalization and promote the early release of patients from hospital beds or stretchers in emergency corridors.

An ad hoc committee was created to prepare the program and establish local guidelines. Nurses prepared a venous access program. Pharmacists prepared written information for patients on intravenous antibiotics, and safety and preparation procedures for each intravenous antibiotic. Infectious disease specialists defined indications (eg, a stable patient) and contraindications (eg, an intravenous drug user) for outpatient intravenous antibiotic therapy. They prepared a list of the antibiotics of choice, with recommended dosage and dosing intervals. For example, they selected cefazoline every $12 \mathrm{~h}$ with probenecid (Benemid, Merck Sharpe \& Dohme Canada, Kirkland, Quebec) (11), use of once daily aminosides (12), the use of clindamycin (Dalacin C, Pharmacia \& Upjohn Inc, Mississauga, Ontario) $1200 \mathrm{mg}$ every $12 \mathrm{~h}$ (13) if minimum inhibitory concentrations of isolate bacteria were low. As another example, intravenous use of ciprofloxacin (Cipro, Bayer Inc, Toronto, Ontario) and metronidazol were restricted because of good bioavilability (more than $80 \%$ ) (14). Infectious disease specialists prepared a routine set of blood tests for toxicity surveillance and recommended drug dosages for each order of intravenous antibiotics (15).

Within three months of the decision to begin the program, an intrahospital ambulatory unit, which occupied a two-bed room in the hospital, was staffed by a nurse seven days/week from 7:00 to 21:00. The unit was supported by a part-time pharmacist and a part-time pharmacist technical assistant. A telephone number for the program was given to each patient admitted to the program. Calls were handled directly by the nurse. The objective of the intrahospital ambulatory unit was to provide an alternative to hospitalization equivalent to 4.5 beds/year and 1.5 stretchers in emergency corridors/year (the equivalent to 2190 bed days/year). 
TABLE 1

Cumulutive data on outpatient antibiotic therapy at Hôpital Charles LeMoyne between January 1, 1996 and

December 31, 1996

\begin{tabular}{lccc}
\hline Results & $\begin{array}{c}\text { Short term } \\
\text { therapy }\end{array}$ & $\begin{array}{c}\text { Long term } \\
\text { therapy }\end{array}$ & All therapy \\
\hline $\begin{array}{l}\text { Number of patients } \\
\begin{array}{c}\text { Outpatient intravenous } \\
\text { treatment mean } \\
\text { duration (days) }\end{array}\end{array}$ & 258 & 85 & 343 \\
$\begin{array}{l}\text { Therapy (days) } \\
\text { Antibiotic mean } \\
\text { acquisition cost } \\
\text { per patient }\end{array}$ & 985 & 19.71 & 7.76 \\
$\begin{array}{c}\text { Antibiotic mean } \\
\text { acquisition cost per day }\end{array}$ & $\$ 51.57$ & $\$ 707.49$ & $\$ 215.47$ \\
$\begin{array}{l}\text { Total antibiotic } \\
\text { acquisition cost }\end{array}$ & $\$ 13,124$ & $\$ 60,136$ & $\$ 73,261$ \\
\hline
\end{tabular}

\section{TABLE 2}

Impact of outpatient intravenous therapy on Hôpital Charles LeMoyne, 1995 and 1996 data

\begin{tabular}{lccc}
\hline & $\begin{array}{c}\text { Outpatient } \\
\text { intravenous } \\
\text { antibiotic } \\
\text { therapy 1996 } \\
\text { data }\end{array}$ & $\begin{array}{c}\text { Hospital } \\
\text { admissions } \\
\text { 1995/96 data on } \\
\text { infectious } \\
\text { diseases }\end{array}$ & $\begin{array}{c}\text { Percentage } \\
\text { outpatient } \\
\text { impact }\end{array}$ \\
\hline $\begin{array}{c}\text { Number of patients } \\
\text { admitted }\end{array}$ & 343 & 2157 & 15.9 \\
$\begin{array}{c}\text { Number of therapy } \\
\text { days }\end{array}$ & 2660 & 8934 & 29.8 \\
\hline
\end{tabular}

Note that $1995 / 96$ is a fiscal period

The admitting physician was the acting physician unless another physician had agreed to take charge of the patient on the following day. Nurses evaluated each patient referred to the unit for mobility, learning ability and past medical history, such as intravenous drug use. Nurses attended to venous access, on-site perfusion, self-administration teaching, and surveillance of bloods tests and side effects. Pharmacists gave information to patients about medications and side effects, and looked for allergies and drug interactions. Pharmacists also checked drug dosages and prepared antibiotics. They also called admitting physicians for verification or a change of prescription when the prescriptions did not conform to locally established guidelines. The program followed differed depending on whether short (two to five days) or long term intravenous antibiotic therapy was prescribed. With short term treatment, the unit served more as an infusion unit and antibiotics were administered in the unit. For long term treatment, the unit provided education and support, and antibiotics were self-administered at home. For patients on long term therapy, vascular radiologists inserted peripherally inserted central catheter (PICC) lines (mainly Groshong, Bard Canada Inc, Mississauga, Ontario) to allow selfadministration of medication with mechanical pumps or programmable pumps.
TABLE 3

Antibiotics use with antibiotic acquisition costs at Hôpital Charles LeMoyne between January 1, 1996 and December 31, 1996

\begin{tabular}{|c|c|c|c|}
\hline Intravenous antibiotics & $\begin{array}{l}\text { Short term } \\
\text { therapy } \\
\text { (acquisition } \\
\text { cost) }\end{array}$ & $\begin{array}{l}\text { Long term } \\
\text { therapy } \\
\text { (acquisition } \\
\text { cost) }\end{array}$ & All therapy \\
\hline Cefazolin & $\begin{array}{c}166 \text { patients } \\
(\$ 5,390)\end{array}$ & $\begin{array}{c}22 \text { patients } \\
(\$ 4,997)\end{array}$ & $\begin{array}{c}188 \text { patients } \\
(\$ 10,388)\end{array}$ \\
\hline Gentamicin/tobramycin & $\begin{array}{c}45 \text { patients } \\
(\$ 1,702)\end{array}$ & $\begin{array}{c}12 \text { patients } \\
(\$ 3,955)\end{array}$ & $\begin{array}{c}57 \text { patients } \\
(\$ 5,657)\end{array}$ \\
\hline $\begin{array}{l}\text { Ceftriaxone (Rocephin, } \\
\text { Hoffmann-La Roche Ltd, } \\
\text { Mississauga, Ontario) }\end{array}$ & $\begin{array}{l}8 \text { patients } \\
(\$ 2,276)\end{array}$ & $\begin{array}{c}23 \text { patients } \\
(\$ 39,899)\end{array}$ & $\begin{array}{c}31 \text { patients } \\
(\$ 42,176)\end{array}$ \\
\hline Vancomycin & $\begin{array}{c}0 \text { patients } \\
(\$ 0)\end{array}$ & $\begin{array}{c}7 \text { patients } \\
(\$ 747)\end{array}$ & $\begin{array}{c}7 \text { patients } \\
(\$ 747)\end{array}$ \\
\hline $\begin{array}{l}\text { Clindamycin (Dalacin C, } \\
\text { Pharmacia \& Upjohn } \\
\text { Inc, Mississauga, } \\
\text { Ontario) }\end{array}$ & $\begin{array}{c}35 \text { patients } \\
(\$ 2,971)\end{array}$ & $\begin{array}{c}18 \text { patients } \\
(\$ 9,629)\end{array}$ & $\begin{array}{c}53 \text { patients } \\
(\$ 12,601)\end{array}$ \\
\hline $\begin{array}{l}\text { Piperacillin-tazobactam } \\
\text { (Tazocin, Wyeth-Ayerst } \\
\text { Canada Inc, St Laurent, } \\
\text { Quebec) }\end{array}$ & $\begin{array}{c}10 \text { patients } \\
(\$ 5,298)\end{array}$ & $\begin{array}{l}4 \text { patients } \\
(\$ 1,402)\end{array}$ & $\begin{array}{c}14 \text { patients } \\
(\$ 5,298)\end{array}$ \\
\hline Total & $\begin{array}{c}258 \text { patients } \\
(\$ 13,124)\end{array}$ & $\begin{array}{c}85 \text { patients } \\
(\$ 60,136)\end{array}$ & $\begin{array}{c}343 \text { patients } \\
(\$ 73,261)\end{array}$ \\
\hline
\end{tabular}

\section{RESULTS}

The results of the first year of operation of the ambulatory care unit, January 1, 1996 to December 31, 1996, are described below. Over that period, 343 patients received outpatient intravenous antibiotic therapy, accounting for 2660 outpatient therapy days (Table 1). This represented 15.9\% (343 of 2157) of bed admissions and $29.8 \%$ (2660 of 8934 ) of bed therapy days for the infectious diseases department at the Hôpital Charles LeMoyne (Table 2). An impressive $81.6 \%$ (280 of 343) patients admitted to the program came directly from the emergency department, or from outpatient hospital clinics or private offices in the community. Hospitalized patients constituted only $18.4 \%$ (63 of 343 ) of admissions to the program. The mean duration of outpatient intravenous antibiotic therapy was 7.76 days. The youngest patient was three years old; the oldest patient was 95 years old (mean age 44.1 years). Cefazolin and gentamicin/tobramycin were the most commonly used antibiotics in short term therapy and in term of number of patients (Table 3). Second-line antibiotics such as ceftriaxone (Rocephin, Hoffmann-La Roche Ltd, Mississauga, Ontario) or vancomycin were used for long term therapy. Total drug acquisition cost was $\$ 73,117$ and constituted $20 \%$ $(\$ 73,117$ of $\$ 373,309)$ of the total cost of the program (Table 4). Over the first year, $40 \%$ of doctors (57 of 143) from the medical/surgical staff participated in the program (Table 5). Infectious disease specialists admitted only $35.6 \%$ of patients (122 of 343). Primary care physicians admitted $37.3 \%$ of patients (128 of 343). The initial goal of 2190 bed days saved was surpassed; 2660 equivalent bed days were saved.

The per diem outpatient cost was \$140/day for the first year versus the hospital per diem cost of $\$ 412 /$ day. A saving of 
TABLE 4

Cumulative cost for outpatient intravenous antibiotic therapy at Hôpital Charles Lemoyne (January 1, 1996 to December 31, 1996)

\begin{tabular}{|c|c|c|c|c|}
\hline & Accounting data & $\begin{array}{c}\text { Annual (1996) cost* for } 343 \\
\text { patients or } 2660 \text { therapy days }\end{array}$ & $\begin{array}{c}\text { Percentage of total } \\
\text { budget }\end{array}$ & Outpatient per diem \\
\hline Total nursing cost & & $\$ 162,092$ & 43 & $\$ 61$ \\
\hline Daily nursing & $\begin{array}{l}\$ 23.03 / \mathrm{h} \times 1.35+\times \\
7 \mathrm{~h} / \text { day } \times 365 \text { days }\end{array}$ & $\$ 82,416$ & 22 & \\
\hline Evening nursing & $\begin{array}{l}\$ 23.03 / \mathrm{h} \times 1.35 \times \\
5 \mathrm{~h} / \text { day } \times 365 \text { days }\end{array}$ & $\$ 59,681$ & 16 & \\
\hline Nursing material & $\$ 7.25 /$ day $\times 2660$ days & $\$ 19,999$ & 5 & \\
\hline Total pharmacy cost & & $\$ 131,405$ & 36 & \\
\hline $\begin{array}{c}\text { Total pharmacy cost without } \\
\text { antibiotics acquisition cost }\end{array}$ & & $\$ 58,144$ & 16 & $\$ 22$ \\
\hline Daily part-time pharmacist & $\begin{array}{c}\$ 30.00 / \mathrm{h} \times 1.35 \times 3 \\
\mathrm{~h} / \text { day } \times 365 \text { days }\end{array}$ & $\$ 44,347$ & 12 & \\
\hline $\begin{array}{l}\text { Part-time pharmacist technical } \\
\text { assistant }\end{array}$ & $\begin{array}{c}\$ 14.00 / \mathrm{h} \times 1.35 \times 2 \\
\mathrm{~h} / \text { day } \times 365 \text { days }\end{array}$ & $\$ 13,797$ & 4 & \\
\hline Antibiotics acquisition cost & & $\$ 73,261$ & 20 & $\$ 27$ \\
\hline Total indirect estimated cost & & $\$ 79,812$ & 21 & $\$ 30$ \\
\hline Social worker estimated cost ${ }^{\ddagger}$ & $\begin{array}{c}\$ 2.00 / \text { therapy day } \times \\
2660 \text { days }\end{array}$ & $\$ 5,332$ & 1 & \\
\hline Archives estimated cost $^{\ddagger}$ & $\begin{array}{l}\$ 8.00 / \text { therapy day } \times \\
2660 \text { days }\end{array}$ & $\$ 21,280$ & 6 & \\
\hline $\begin{array}{l}\text { Radiology and laboratory } \\
\text { estimated cost }{ }^{\ddagger}\end{array}$ & $\begin{array}{c}\$ 20.00 / \text { therapy day } \times \\
2660 \text { days }\end{array}$ & $\$ 53,200$ & 14 & \\
\hline $\begin{array}{l}\text { Total outpatient intravenous } \\
\text { antibiotic therapy cost }\end{array}$ & & $\$ 373,309$ & 100 & $\$ 140$ \\
\hline
\end{tabular}

$\$ 272 /$ day (66\% of hospital per diem cost) was realized, and an annual saving of $\$ 725,000$ was generated (Table 6). Nursing costs were $\$ 61 /$ day. Pharmacists cost without drug acquisition cost was $\$ 22 /$ day. Indirects costs were estimated at $\$ 30 /$ day (Table 4).

When the data were analyzed more closely, two types of patients were seen (Tables 7,8 ). One group of patients was admitted mainly by primary physicians for empirical, outpatient intravenous antibiotic therapy for skin or soft tissue, or urinary tract infections. The mean duration of intravenous antibiotic therapy for this group was 3.8 days, with an antibiotic acquisition cost per patient of $\$ 51.57$ (Table 3 ). This group was largest in terms of the number of patients $(n=258)$, but generated the smallest days in hospital days saved $(n=985)$. Primary physicians cared for $49.6 \%$ (128 of 258) of those patients. The other group of patients was admitted mainly by microbiology/infectious disease specialists, and underwent specific outpatient intravenous antibiotic therapy for bone or joint, deep organ or opportunistic infections. The mean duration of intravenous antibiotic therapy was 19.7 days for this group, with an antibiotic acquisition cost per patient of $\$ 707.49$ (Table 3). This group was the smallest in the number of patients $(n=85)$ but generated the largest days in hospital saved $(n=1675)$. Infectious disease specialists cared for $74 \%$ (64 of 85 ) of these patients.

The antibiotics used differed between the groups. The empirical, short term therapy group used mainly cefazolin and gentamicin/tobramycin. The specific, long term treatment group used mainly ceftriaxone and vancomycin. Clindamycin and piperacillin-tazobactam (Tazocin, Wyeth-Ayerst Canada
TABLE 5

Participation of active medical/surgical staff at Hôpital Charles LeMoyne in the outpatient antibiotics program between January 1, 1996 and December 31, 1996

\begin{tabular}{lcc}
\hline Type of admitting physicians & $\begin{array}{c}\text { Number of } \\
\text { participating } \\
\text { physicians/total } \\
\text { active physicians }\end{array}$ & $\begin{array}{c}\text { Number of } \\
\text { admitted } \\
\text { patients }\end{array}$ \\
\hline Emergency primary physicians & $16 / 24$ & 68 \\
Hospital-based primary & $14 / 16$ & 60 \\
physicians & $0 / 9$ & \\
Neurologists & $0 / 7$ & 0 \\
Cardiologists & $0 / 6$ & 0 \\
Pneumologists & $2 / 6$ & 0 \\
Gastroenterologists & $2 / 2$ & 2 \\
Nephrologists & $0 / 2$ & 34 \\
Rheumatologists & $0 / 2$ & 0 \\
Dermatologists & $0 / 4$ & 0 \\
Hemato-oncologists & $2 / 8$ & 0 \\
Internists & $3 / 3$ & 5 \\
Infectious disease specialists & $1 / 8$ & 122 \\
Pediatrists & $2 / 4$ & 1 \\
Ophthalmologists & $4 / 10$ & 2 \\
Otorhinolaryngologists & $0 / 4$ & 7 \\
Neurosurgeons & $2 / 3$ & 0 \\
Plastic surgeons & $2 / 4$ & 13 \\
General surgeons & $1 / 3$ & 2 \\
Vascular surgeons & $3 / 7$ & 1 \\
Orthopedists & $2 / 3$ & 843 \\
Urologists & $1 / 8$ & \\
Gynecologists & $57 / 143(40 \%)$ & \\
Total & & \\
\hline & & 17 \\
\hline
\end{tabular}


TABLE 6

Efficiency of clinical re-engineering process at Hôpital Charles LeMoyne

\begin{tabular}{|c|c|c|c|c|}
\hline 1996 & Condition & $\begin{array}{c}\text { Per diem } \\
\text { cost }\end{array}$ & $\begin{array}{c}\text { Annual cost for } \\
343 \text { patients or } \\
2660 \\
\text { therapy-days }\end{array}$ & $\%$ \\
\hline $\begin{array}{l}\text { Outpatient } \\
\text { setting }\end{array}$ & $\begin{array}{l}2660 \text { out- } \\
\text { patient } \\
\text { therapy } \\
\text { days }\end{array}$ & $\$ 140$ & $\$ 373,309$ & 34 \\
\hline $\begin{array}{l}\text { Hospital } \\
\text { setting }\end{array}$ & $\begin{array}{c}2660 \text { bed } \\
\text { therapy } \\
\text { days }\end{array}$ & $\$ 412$ & $\$ 1,098,392$ & 100 \\
\hline $\begin{array}{l}\text { Hospital } \\
\text { savings }\end{array}$ & & $\$ 272$ & $\$ 725,083$ & 66 \\
\hline
\end{tabular}

TABLE 7

Types of patients on outpatient intravenous antibiotic therapy

\begin{tabular}{lc}
\hline Short term therapy & Long term therapy \\
\hline No other disease & Multiple chronic diseases \\
$\begin{array}{c}\text { Minimal diagnosis; work up } \\
\text { without hospitalization }\end{array}$ & Extensive diagnosis; work up with \\
initial hospitalization \\
$\begin{array}{c}\text { Skin/soft tissue infections; } \\
\text { urinary tract infections }\end{array}$ & Bone/joint infections; deep organ \\
& infections; opportunistic \\
Primary physicians; & infections \\
surgical/medical specialists & Infectious disease specialists; \\
Empirical therapy (with & selected specialists \\
guidelines) & Specific therapy (based on isolate \\
Two to five days therapy + oral & agents and site) \\
sequential therapy & Seven to 42 days therapy \\
Hospitalization prevention saving & Hospitalization duration saving \\
\hline
\end{tabular}

Inc, St Laurent, Quebec) were used in both groups. Antibiotic acquisition cost per day was low (\$13.32) in the empirical, short term therapy group and high $(\$ 35.90)$ in the specific, long term therapy group (Table 3$)$. Ceftriaxone $(\$ 42,172)$ and clindamycin $(\$ 12,456)$ accounted for $74.7 \%$ of the total antibiotic acquisition cost. Cefazolin $(\$ 10,388)$, with the highest antibiotic use in terms of therapy-days, was third in terms of antibiotic acquisition cost.

\section{CONCLUSIONS}

At Hôpital Charles LeMoyne, in 1996, we were able to convince a large medical/surgical staff to make a significant change in the practice of intravenous antibiotic therapy. This change significantly affected the daily management of hospital beds and number of stretchers in emergency department corridors. These results confirmed the results of previous pilot studies in the province of Quebec regarding savings, even with different definitions of data.

Our experience showed that two types of patients can benefit from outpatient intravenous antibiotic therapy: a group on empirical, short term therapy, which can be switched to an oral antibiotic after an initial clinical response; and a group on
TABLE 8

Type of outpatient intravenous antibiotics therapy

\begin{tabular}{ll}
\hline Short term therapy & Long term therapy \\
\hline $\begin{array}{l}\text { First-line antibiotics } \$ 25 \text { to } \\
\$ 100 / \text { patient/therapy }\end{array}$ & $\begin{array}{c}\text { Second-line antibiotics } \$ 200 \text { to } \\
\$ 1000 / \text { patient/therapy }\end{array}$ \\
$\begin{array}{ll}\text { Administration by gravity } & \text { Self-administration with mechanical } \\
\text { or programmable pump }\end{array}$ \\
$\begin{array}{ll}\text { Short term peripheric catheter } & \text { Long term peripherically inserted } \\
\text { central catheter }\end{array}$ \\
$\begin{array}{l}\text { No antibiotic monitoring } \\
\text { No patients training }\end{array}$ & $\begin{array}{c}\text { Closed antibiotic monitoring } \\
\text { Two to four days medical } \\
\text { follow-up }\end{array}$ \\
\hline
\end{tabular}

specific long term therapy, for which the therapy results in significant cost savings and significant improvement in the quality of life of those patients. Our experience shows that primary physicians can accept responsibility for empirical, short term outpatient intravenous therapy with first-line antibiotics. Hospitals that want to make a significant impact on hospital bed resources or stretchers in emergency department corridors would be advised to develop an outpatient facility for both groups of patients.

\section{REFERENCES}

1. Martel AY, Bergeron MG. Antibiothérapie parentérale à domicile : experience au Centre Hospitalier de l'Université Laval. Union méd Can 1987;116:190-3.

2. Gourdeau M, Deschesnes L, Caron M, Desmarais M. Home IV antibiotic therapy through a medical day care unit. Can J Infect Dis 1993;4:158-62.

3. Martel AY. Home intravenous self-injection of antibiotic therapy. Can J Infect Dis 1994;5(Suppl C);51C-55C.

4. Ministère de la Santé et des Services Sociaux. Evaluation de l'efficience hospitalière dans le cadre du défi "qualitéperformance". Direction générale du budget et de l'administration. Québec : Ministère de la Santé et des Services Sociaux, Juin 1994.

5. Stiver HG, Trossky SK, Cote DD. Self-administration of intravenous antibiotics: an efficient, cost-effective home care program. Can Med Assoc J 1982;127:207-11.

6. Stiver HG, Telford GO, Mossey JM. Intravenous antibiotic therapy at home. Ann Intern Med 1979;139:413-5.

7. Tice AD. An office model of outpatient parenteral antibiotic therapy. Rev Infect Dis 1991;13(Suppl 2):S184-8.

8. Poretz DM. The Infusion Center: A model for outpatient parenteral antibiotic therapy. Rev Infect Dis 1991;13(Suppl 2):S142-6.

9. Williams DN. Home intravenous antibiotic therapy (HIVAT): Indications, patients and antimicrobial agents. Int J Antimicrob Agents 1995;5:3-8.

10. Canadian Advisory Committee on Home IV Antibiotic Therapy. Canadian Home IV Guidelines. Toronto, November 11-12, 1994.

11. Brown G, Zemcov SJV, Clarke AM. Effect of probenecid on cefazolin serum concentrations. J Antimicrob Chemother 1993;31:1009-11.

12. Gilbert DN. Once-daily aminoglycoside therapy. Antimicrob Agents Chemother 1991;35:399-405.

13. Craig WA. Kinetics of antibiotics in relation to effective and convenient outpatient parenteral therapy. Int J Antimicro Agents 1995;5:19-22.

14. Jewesson PJ. Pharmaceutical, pharmacokinetics and other considerations for intravenous to oral stepdown therapy. Can J Infect Dis 1995;6(Suppl A):11A-16A.

15. Brown RB. Selection and training of patients for outpatient intravenous antibiotic therapy. Rev Infect Dis 1991;13(Suppl 2):S147-51. 


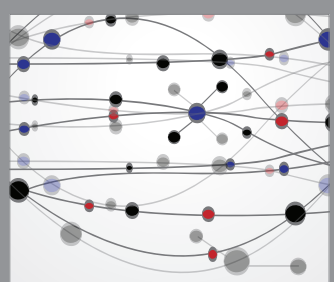

The Scientific World Journal
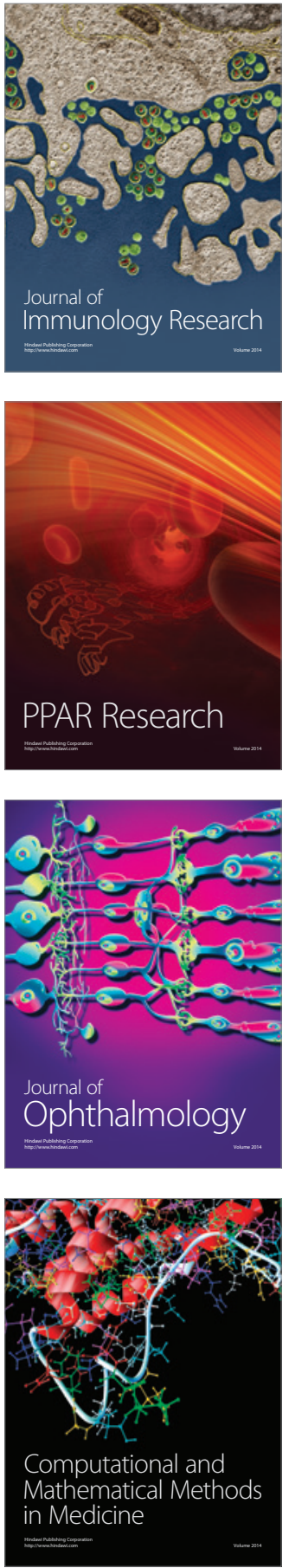

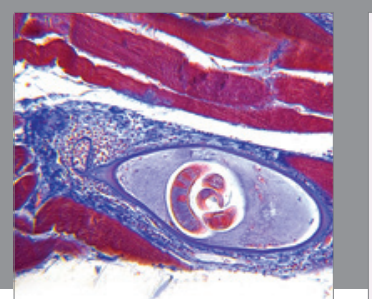

Gastroenterology Research and Practice

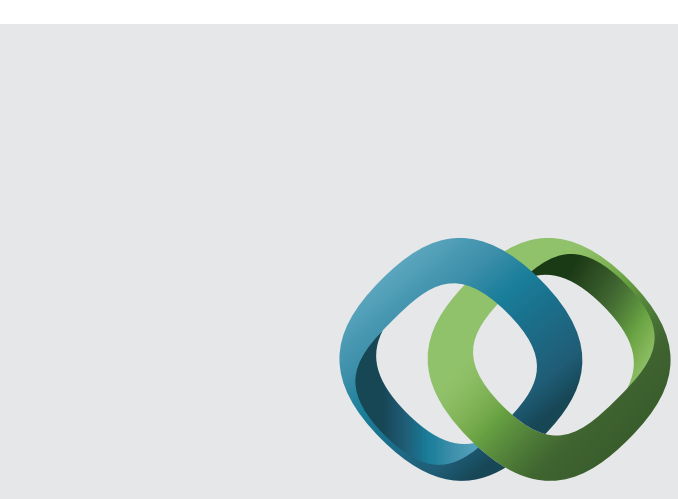

\section{Hindawi}

Submit your manuscripts at

http://www.hindawi.com
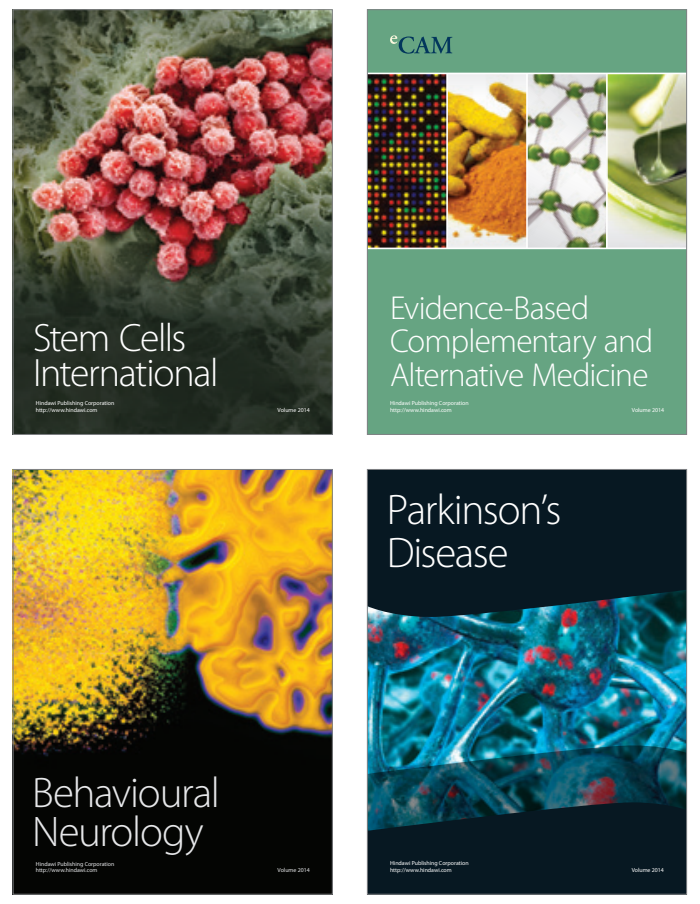
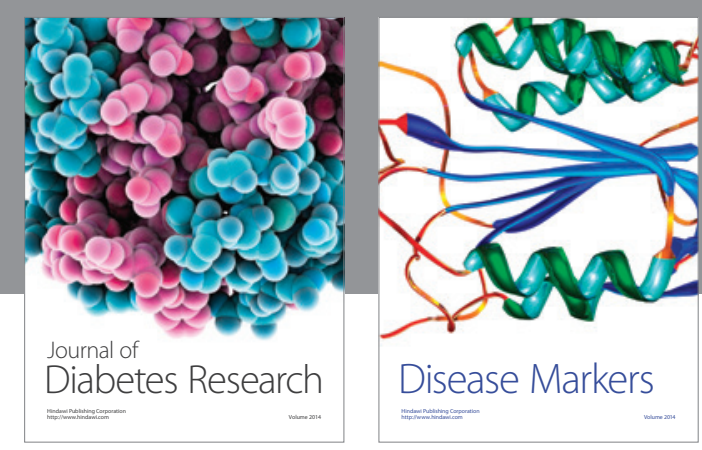

Disease Markers
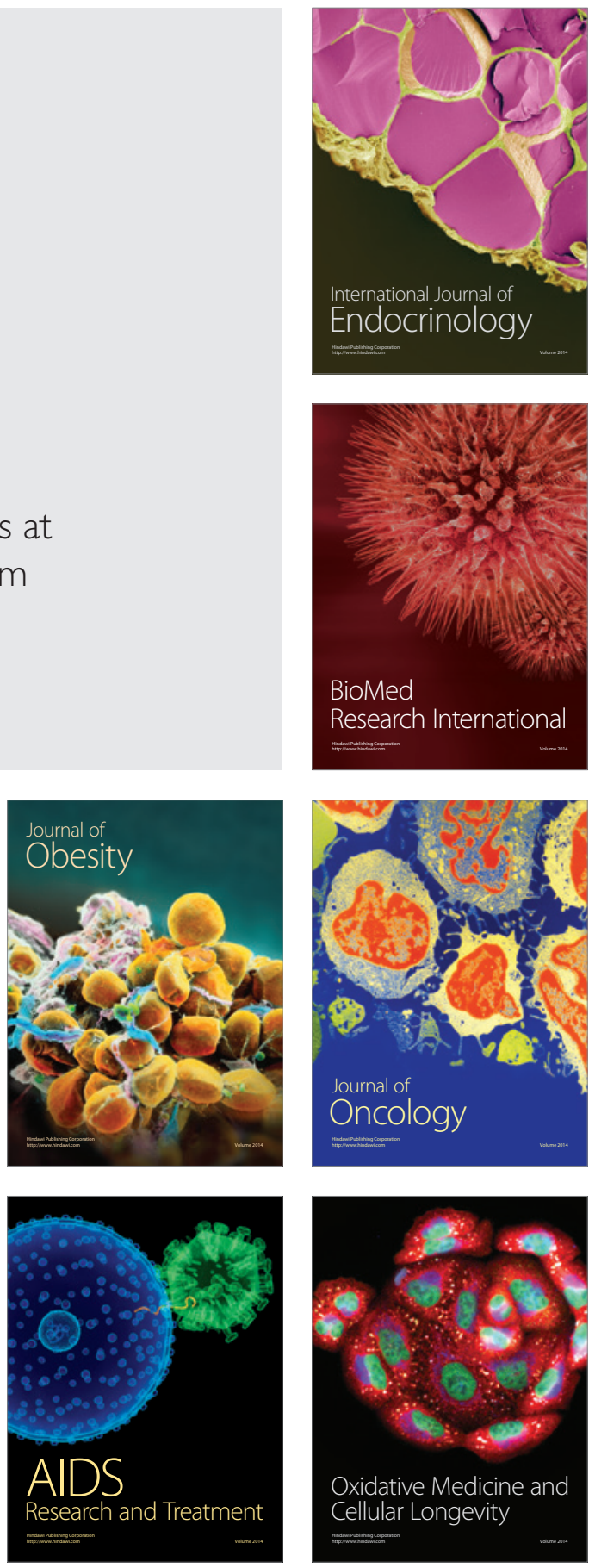